\title{
A DETERMINAÇÃO DAS PARTES LUCRI ET DAMNI NO CONTRATO DE SOCIEDADE ROMANO
}

\author{
Danilo Borges dos Santos Gomes de Araujo( ${ }^{*}$ \\ "Dottorando di ricerca" na Università degli Studi di Roma \\ "Tor Vergata"
}

Resumo:

Sob uma perspectiva exegética das fontes do Direito Romano (mormente aquelas em Gai 3,149, I. 3,25,2, D. 17,2,29,1 e D. 17,2,30), este texto centra-se na descrição dos debates - surgidos na Jurisprudência tardorepublicana entre Quinto Múcio e Sérvio Sulpício - sobre a possibilidade, na societas romana, de se fixar, para o mesmo sócio, uma quota de lucros diversa da sua quota de danos, até o caso extremo em que um sócio ficasse totalmente isento dos danos ainda que participasse dos lucros, hipótese que normalmente se identifica com o fato de que o sócio isento é aquele que aporta opera em comum.

\begin{abstract}
:
Under an exegetic perspective of the roman law texts (mainly those at Gai. 3,149, I. 3,25,2, D. 17,2,29, I e D. 17,2,30), this article focus on the description of the debates - arisen in the late-republican jurisprudence between Quintus Mucius and Servius Sulpicius-about the possibility, in the roman societas, of assigning, to the same partner, a profits quota diverse from his losses quota, till the extreme case in which a partner were totally exempted from the losses, even though sharing the profits, hypothesis that is regularly identified with the fact that the exempted partner is the one who contributed opera towards the partnership.
\end{abstract}

Unitermos: societas; quota de lucros e de danos; Jurisprudência tardo-republicana.

§1. Introdução. Plano de exposição do trabalho.

Arangio-Ruiz oferece a seguinte definição do contrato de sociedade romano: "Un contratto consensuale e bilaterale (od anche, all'occasione, plurilaterale), senza riflessi sulla posizione dei contraenti in confronto dei terzi, in virtù del quale due o più persone s'impegnano a mettere in comune beni ed attività allo scopo di dividerne secondo una proporzione prestabilita i profitti e le perdite" '

$\left(^{*}\right)$ O presentc texto foi apresentado como trabalho final da disciplina "Excgese das fontes de Dircito Romano", por nós cursada como parte do programa de "Dottorato di ricerca" que sc freqüenta na Università degli Studi di Roma "Tor Vergata".

1. Arangio-Ruiz, La società in diritto romano. Corso di lezioni svolto nell'Università di Roma anno 1949-1950, rcedição anastática, Napoli, 1965, p. 63. 
Ressalvando-se que tal definição não é extraída imediatamente das fontes, mas é o resultado de um esforço conceitual de um autor moderno, verifica-se que, das fontes romanas, é possível deduzir os seguintes elementos do contrato de sociedade romano:2 i. a consensualidade; ii. a bi ou plurilateralidade; iii. a plena estranheza perante terceiros; iv. as contribuições dos sócios; e v. a repartição, entre os sócios, dos lucros ou das perdas.

A discussão jurisprudencial que será objeto desse trabalho circunscrevese a dois dos elementos supramencionados, aqueles $s u b$ "(iv)" e sub "(v)" Ou seja, circunscreve-se aos temas das conferições a serem aportadas pelos contratantes e das quotas de repartição dos lucros e das perdas. Com efeito, em todo o contrato de sociedade, duas ou mais pessoas comprometem-se a colocar em comum bens e atividades e dividir os lucros e as perdas segundo uma proporção preestabelecida. ${ }^{3}$ Porém, essas duas características do contrato de sociedade são objeto de algumas importantes discussões entre os jurisprudentes romanos.

Em primeiro lugar, examinando as disposições contratuais que tratam dos aportes dos sócios, especial atenção se volta para o problema da heterogeneidade dos aportes, destacando-se aquele caso peculiar em que um sócio aporta o capital e o outro sócio faz a contribuição em opera. Tal apresentação se fará no $§ 2$ do texto.

Tendo em vista que a heterogeneidade dos aportes foi admitida pelo Direito Romano, ainda mais porque a praxe econômica certamente a impôs, o problema então se transfere para um outro elemento do contrato de sociedade: a determinação das partes lucri et damni. Ora, a heterogeneidade dos aportes pressupõe que os sócios, eventualmente, possam também querer diversificar as proporções de divisão dos lucros e dos danos, sobretudo com o intuito de harmonizá-las com a não-homogeneidade das contribuições.

Esse problema, abrangido por todo o $§ 3$ deste trabalho, será afrontado a partir das três vias pelas quais os contratantes podem, no Direito Romano, dispor a respeito das partes lucri et damni: silenciando-se $(\$ 3.1)$, determinando-as expressamente através de pacto (\$3.2) ou, por último, encarregando um árbitro de fazer a determinação (\$3.3). Para cada uma dessas três vias existem soluções e discussões próprias narradas pelas fontes.

O núcleo do presente trabalho está naquela segunda via, ou seja, quando a determinação das quotas de participação nos lucros e nas perdas é objeto de uma expressa convenção dos contratantes. Mais precisamente, interessam aqueles casos em que a determinação das partes foge da concepção paritária de divisão dos lucros e das perdas. À tona vêm as questões a respeito de quais as convenções válidas e, quando válidas, dentro de quais limites.

É justamente nesse contexto que desponta a magna quaestio que, conforme se narra em Gai. 3,149 - mas também reportada por outras fontes -, teria

2. Ressalva-se, também, que falar $\mathrm{cm}$ clementos do contrato ć um discurso pandectista, scndo aqui apresentada uma definição do contrato de sociedade romano apenas para fins de delimitação do campo de cstudo, ou melhor, para que melhor se comprecnda o âmbito temático da discussão jurisprudencial cuja cvolução scrá investigada.

3. Assim Arangio-Ruiz, La società cit. (nota I), p. 93. 
surgido a partir da dissensão entre os juristas republicanos Quinto Múcio Cévola e Sérvio Sulpício Rufo, em tema de eventual atribuição, a um mesmo sócio, de quota de lucros diferente da quota de danos.

Tendo prevalecido a tese de Sérvio Suplício, o debate se desloca para o problema dos eventuais limites e condições de admissibilidade da diferente quotização, para um mesmo sócio, dos lucros e das perdas.

Por fim, aproveitando a oportunidade que uma discussão entre Quinto Múcio e Sérvio Sulpício sói oferecer, serão apresentadas no $\$ 4$ as características da Jurisprudência tardo-republicana, o seu contexto histórico e a sua contribuição para a formação do ius civile romano.

\section{§2. A obrigação de aportar a contribuição convencionada.}

É obrigação dos sócios dar a contribuição prometida. Tratando-se de contribuição de coisas materiais, estas devem ser colocadas em comum. ${ }^{4}$ Se para um dos contratantes não existir a obrigação de fazer qualquer contribuição, então, com relação a ele, não existirá sociedade, mas doação, conforme se afirma em Ulp. 31 ad ed., D. 17,2,5,1. ${ }^{5}$

Em tema de aporte da contribuição convencionada, três interessantes questões emergem: ${ }^{6}$ i. o problema de quem deve suportar o risco se a coisa colocada em comum perecer por caso fortuito, sendo, para esse problema, importantes as passagens em Ulp. 31 ad ed., D. 17,2,58 pr. $^{7}$ e $1^{8}$; ii. o problema do sócio moroso da

4. Cf. Amò, Il contratto di società. Corso di diritto romano. Lezioni raccolte dagli studenti F. Palieri $e$ G. Berto. Anno accademico 1936-37-XV, Torino, 1938, p. 169. Pode-se conferir a propricdade ou o uso da coisa; se se conferir a propricdade, esta se transforma $\mathrm{cm}$ condominio de todos os sócios, scndo que, $\mathrm{cm}$ ćpoca pré-justinianćia, o aportc da coisa se faz, dependendo da sua qualidade, com a mancipatio ou com a traditio (cf. ARNò, Arnóll contratto di società cit. (nota 4), pp. 174-175).

5. Ulp. 31 ad ed., D. 17,2,5,1: "Societas autem coiri potest et valet etian inter eos, qui non sumt aequis facultatibus, cum plerumque pauperior opera suppleat, quantum ei per comparationem patrimonii deest. donationis causa societas recte non contrahitur."

6. Esscs problemas são, aqui, apenas accnados. Para uma discussão mais aprofundada das soluçõcs juridicas desses problemas, remetc-se a Amò, /l contratto di società cit. (nota 4), pp. 175-185.

7. Ulp. 31 ad ed., D. 17,2,58 pr.: "Si id quod quis in societatem contulit exstinctum sit, videndum, an pro socio agere possit. tractatum ita est apud Celsum libro septimo digestorum ad epistulam Cornelii Felicis: cum tres equos haberes et ego unum, societaten coimus, ut accepto equo meo quadrigam venderes et ex pretio quartam mihi redderes. si igitur ante venditionem equus meus mortus sit, non putare se Celsus ait societatem manere nec ex pretio equorum tuortm partem deberi: non enim habendae quadrigae, sed vendendae coitan societatem. ceterum si id actum dicatu; ut quadriga fieret eaque communicaretur tuque in ea tres partes haberes, ego quartan, non dubie adlhuc socii sumus."

8. Ulp. 31 ad ed., D. 17,2,58, I: "Item Celsus tractat, si pecuniam contulissemus ad mercem emendam et mea pecunia perisset, cui perierit ea. et ait, si post collationem evenit, ut pecunia periret, quod non fieret, nisi societas coita esset, utrique perire, ut puta si pecunia, cum peregre portaretur ad mercem emendam, periit: si vero ante collationem, posteaquam eam destinasses, tunc perierit, nihil eo nomine consequeris, inquit, quia non societati periit." 
obrigação de conferir, que se discute em Pomp. 13 ad Sab., D. 17,2,60 pr.' ; e iii. o problema de a quem atribuir a responsabilidade pela evicção e pelos vícios ocultos da coisa transferida. ${ }^{10}$

Os aportes dos sócios podem não ser homogêneos. Eram-no naquele tipo primordial de sociedade, o consórcio ercto non cito, que ainda não se constituía por contrato, mas espontaneamente surgia entre heredes sui ou se constituía entre estranhos por meio da certa legis actio de que se fala em Gai. 3,154a. Em qualquer dos casos, eram colocados ou deixados em comum todos os bens da herança do ancestral ou que constituíam o patrimônio de cada um dos estranhos - coisas corpóreas e também incorpóreas (como o direito de patronato sobre os libertos e os créditos) -, e toda a atividade dos consorciados deveria ser dirigida ao aproveitamento de tais bens segundo a sua normal destinação, ou segundo aquela estabelecida por acordo. O mesmo acontecia, em época progressiva, com a societas omnium bonorum, com os tipos a ela afins e com vários outros casos de sociedade cujo objeto era o aproveitamento de uma ou mais coisas corpóreas."

Advém a heterogeneidade dos aportes à medida que surgem as sociedades industriais e comerciais, ou seja aquelas sociedades em que sócios capitalistas empregam dinheiro ou bens associando-se com industriais e comerciantes dispostos a fornecer a sua experiência e atividade. ${ }^{12}$ Nesse ponto, as contribuições dos sócios tornam-se heterogêneas, não sendo mais do mesmo valor, gênero e natureza, sendo possível até que um sócio faça somente o aporte de capital e um outro somente a conferição de

9. Pomp. 13 ad Sab., D. 17,2,60 pr.: "Socium, qui in eo, quod ex socielate lucri faceret, reddendo, moram adhibuit, cum ea pecunia ipse usus sit, usuras quoque eum praestare debere Labeo ait, sed non quasi usuras, sed quod socii intersit moram eum non adhibuisse: sed si aut usus ea pecunia non sit aut moram non fecerit, contra esse: item post mortem socii nullam talem aestimationem ex facto heredis faciendam, quia morte socii dirimatur societas."

10. Esse problema é resolvido com base nos princípios gerais dos contratos e por analogia ao contrato de compra e venda (cf. Arnò, Il contratto di società cit. (nota 4), pp. 184-185).

11. Cf. Arangio-Ruiz, La societì cit. (nota 1), p. 93.

12. Cf. Arangio-Ruiz, La società cit. (nota I), p. 94. V., também, Bretone, Storia del diritto romano3, Roma-Bari, 1989, pp. 119-139, em que se aponta como, no período dos dois últimos séculos a.C., as difusas práticas comerciais influenciaram sobremaneira a formação do Direito, tendo aí surgido, inclusive, as formas consensuais dos contratos, tuteladas ex fide bona, entre eles a societas consensu contracta.

13. É exemplo desse tipo de sociedade aquela que se formou entre Fânio e Róscio, conforme relata Cícero na oração Pro $Q$. Roscio Comoedo. A fattispecie da controvérsia que se instaurou pode ser assim relatada (cf. S. Riccobono Jr., Capacità manageriale e partecipazione agli utili nella "societas" romana (Gai. 3,148-149), in Atti del seminario sulla problematica contrattuale in diritto romano. Milano, 7-9 aprile 1987, I, Milano, 1988, pp. 225-227): G. Fânio Cherea era em sociedade com o ator Q. Róscio Galo para o fim de repartição dos ganhos da atividade artística de Panurgo, escravo de propriedade de Fânio, mas que tinha recebido de Róscio a instrução teatral. Panurgo foi assassinado por um tal Q. Flávio, nascendo contra este, por parte de Róscio, uma ação de ressarcimento de danos. Iniciado o processo, 
opera..$^{13}$ A opera a ser aportada pode abranger a mais variada gama de atividades humanas, desde a complexa administração da sociedade até a simples execução de um trabalho manual. É nesse contexto que despontam as discussões sobre as relações entre capital e trabalho, debatendo-se se é possível colocar no mesmo nível indústria humana e capital. ${ }^{14}$

A impossibilidade de um tratamento unitário dos aportes (dada a imensa casuística que a prática poderia oferecer) e a imposição prática da heterogeneidade das contribuições fizeram com que a atenção dos juristas se deslocasse para o modo de repartição dos lucros e das perdas, discutindo-se, então, a admissibilidade e, caso admissível, os limites da não-paridade entre a quota de lucros e a quota de danos. ${ }^{15} \mathrm{O}$ deslocamento da atenção dos juristas para esse segundo tema tem a ver com a circunstância de que a heterogeneidade dos aportes poderia, eventualmente, conduzir os sócios a pactuar quotas de retirada dos lucros e dos danos também heterogêneas.

\section{A participação nos lucros e nas perdas.}

Os sócios têm o direito de participar nos lucros e a obrigação de participar nas perdas. São três as vias pelas quais se pode dispor, em um contrato de sociedade, sobre a divisão dos lucros e das perdas: a. os sócios podem silenciar-se a respeito, nada estatuindo a respeito das quotas sociais; b. os sócios podem fixar, de comum acordo, a proporção pela qual a repartição deve ser feita; e c. o encargo de determinar

contudo, faz Róscio uma transação com Flávio. Passados alguns anos, Fânio reclamåa sua parte de Róscio, o qual opõe que a sua transação concernia somente à sua parte, e não a ambas. Em trecho do discurso, Cícero (Pro Com., 10,27-30) alega que o corpo do escravo Panurgo, conferido por Fânio, pouco valia, enquanto era "ars pretiosa" a arte ensinada por Róscio, que, com a sua bravura de ator, permitiu que o escravo tivesse excelente e prestigiosa formação profissional. Sobre os vários aspectos jurídicos pelos quais a oração pode ser estudada, v. Costa, Cicerone giureconsulto2, Bologna, 1927, pp. 166-189.

A propósito, os problemas discutidos nesse texto por ocasião do Direito Romano trazem à lembrança o tipo legal da sociedade de capital e indústria, previsto como tipo autônomo nos artigos 317 a 324 do Código Comercial brasileiro de 1850. Para uma primeira abordagem sobre a moderna sociedade de capital e indústria, v., para todos, Bulgarell, Sociedades comerciais. Sociedades civis e sociedades cooperativas. Empresa e estabelecimento comercial. Estudo das sociedades comerciais e seus tipos, conceitos modernos de empresa e estabelecimento, subsidios para o estudo do direito empresarial, abordagem às sociedades civis e cooperativa.s6, São Paulo, 1996, pp. J00-114. Salienta-se, por fim, que a sociedade de capital e indústria não é contemplada pelo novo Código Civil como um tipo definido de sociedade.

14. Segundo Arnò, Il contratto di societc̀ cit. (nota 4), p. 171, a contraposição entre Quinto Múcio e Sérvio Sulpício teria surgido, antes de mais nada, quanto à possibilidade ou não de se equiparar (no plano moral, inclusive) contribuição de capital e contribuição de obra, ou seja, a contraposição entre os dois juristas republicanos existiria antes mesmo da discussão sobre a deterıninação das partes luc ri et damui, sendo que essa discussão seria tão-somente um reflexo daquela. Segundo a doutrina de Quinto Múcio, afirma ainda Arnò, o trabalho deveria ser sempre mais prestigiado, enquanto para Sérvio Sulpício o trabalho poderia ser colocado em pé de igualdade com o capital. Não obstante a imposição prática da heterogeneidade das contribuições, teria permanecido a dissensão entre mucianos, que pretenderiam um equilíbrio entre a conferição que um sócio faz de capital e a que o outro sócio faz de trabalho, e servianos, para os quais tal equilíbrio não precisaria ocorrer.

15. Cf. Arangio-Ruiz, La società cit. (nota 1), p. 94. 
a proporção das quotas pode ser dado a um dos próprios sócios ou a um estranho. ${ }^{16}$

Dada a diversidade de tratamento e das soluções jurídicas apresentadas nas fontes, cada uma dessas hipóteses será sucessivamente examinada em itens separados. Com relação à primeira via (sub "á"), a apresentação que se fará será mais esquemática e menos.aprofundada. Quanto à segunda via.(sub "b"), que é propriamente o âmbito no qual desponta a discussão iniciada com Quinto Múcio e Sérvio Sulpício, os textos que reportam o debate serão objeto de verdadeira exegese, buscando-se captar todas as variáveis e problemas envolvidos. Com relação à terceira via (sub "c"), tratase de problema que, embora ainda vinculada ao tema da determinação das partes lucri et damni, será aqui tão-somente anunciado, vez que as suas peculiaridades exigiriam um tratamento específico que não pode ser afrontado nesta sede.

\subsection{Ausência de disposição sobre a divisão dos lucros e das perdas.}

Se nada se dispuser a respeito, tanto em época clássica quanto em época justinianéia, as quotas dos lucros e das perdas serão iguais para todos os sócios (Gai. $3,150^{17}$, parte inicial: "et illud certum est, si de partibus lucri et damni nihil inter eos convenerit, tamen aequis ex partibus commodum ut incommodum inter eos commune esse"; Ulp. 30 ad Sab., D. 17,2,29 pr. ${ }^{18}$ parte inicial: "si non fuerint partes societati adiectae, aequas eas esse constat"; e I. 3,25,1 $1^{19}$, parte inicial: "et quidem si nihil de partibus lucri et damni nominatim convenerit, aequales silicet partes et in lucro et in damno spectantur"), ainda que desiguais tenham sido os respectivos aportes.

Embora a doutrina mais recente já tenha superado esse quesito ${ }^{20}$ vale ressaltar que a igualdade propugnada pelas fontes é aquela proporcional às partes viriles, e não às conferições de cada um dos sócios. As expressões usadas pelas fontes "aequales partes" (I. 3,25,1), "aequas" (D. 17,2,29 pr.) e "aequis ex partibus" (Gai. $3,150)$ - não deixam dúvidas de que se trata das partes viriles. ${ }^{21}$ Se se quisesse referir

16. Assim as apresenta Arnò, ll contratto di societì cit. (nota 4), pp. 187-188.

17. Gai. 3,150: "Et illud certum est, si de partibus lucri et damni nihil inter eos convenerit, tamen aequis ex partibus commodum ut incommodum inter eos commune esse; sed ill altero partes expresscte fuerint, veluti in lucro, in altero vero omissae, in eo quoque, quod omissum est, similes partes erunt."

18. Ulp. 30 ad Sab., D. 17,2,29 pr.: "Si non fuerint partes societati adiectae, aequas eas esse constat. si vero placuerit, ut quis duas partes vel tres habeat, alius unam, an valeat? placet valere, si modo aliquid plus contulit societati vel pecuniae vel operae vel cuiuscumque alterius rei causa."

19. I. 3,25,1: "Et quidem si nihil de partibus lucri et damni nominatim convenerit, aequales silicet partes et in lucro et in damno spectantur. Quod si expressate fuerint partes, hae servari debent; nec enim umquam dubium fuit, quin valeat conventio, si duo inter se pacti sunt, ut ad unum quidem duae parles et damni et lucri pertineant, ad alium tertia."

20. Assim Talamanca, Società in generale (diritto romano), in ED, XLII, Milano, 1990, p. 835, nt. 233.

21. Cf. Talamanca, Societì in generale cit. (nota 20), p. 835, nt. 233; Arangio-Ruiz, La societì cit. (nota 1), p. 103 s.; Arnò, Il contratto di societì cit. (nota 4), pp. 189-193; e Cancelli, Societù (diritto) romano), in NNDI, XVII, Torino, 1970, pp. 501-502. 
à igualdade relativa, ou seja, proporcional ao aporte de cada um dos sócios, não se diria "aequales partes" ou "aequis ex partibus", mas "pro rata" e "pro portionibus".,2 Com efeito, o termo "aequae" significa "igual", e, se assim não se entendesse a expressão "aequales partes" seria impossível determinar o valor da opera do sócio de indústria $\mathrm{e}$, consequentemente, admitir a heterogeneidade dos aportes. ${ }^{23}$

Surgem, então, as seguintes dúvidas: por que, por via de presunção, igualar as quotas quando as conferições não são iguais? Por que, silentes os contratantes, não se faz a divisão dos ganhos e das perdas de modo proporcional às contribuições? A resposta que se oferece é a de que, se assim não quisessem os contratantes, não se silenciariam a respeito de um ponto tão essencial, correndo, portanto, a presunção em favor da igualdade das quotas, ainda que desiguais as conferições. ${ }^{24}$

Se o silêncio dos contratantes se restringir somente ao lucro ou somente ao dano, então o elemento não fixado deve ter a mesma medida do elemento fixado (Gai. 3,150, parte final: "sed in altero partes expressae fuerint, veluti in lucro, in altero vero omissae, in eo quoque, quod omissum est, similes partes erunt"; e 1. 3,25,325: "si in una causa pars fuerit expressa, veluti in solo lucro vel in solo damno, in altera vero omissa: in eo quoque quod praetermissum est eandem partem servari”).

3.2. Expressa determinação das quotas dos lucros e dos danos.

Quanto à hipótese em que os próprios sócios fixam as quotas, estabelecendo-se que a repartição deve ser feita nesta ou naquela proporção, as indagações

22. Cf. Arnò, Il contratto di società cit. (nota 4), p. 193. No entanto, opinam favoravel mente a quotas proporcionais aos aportes, por exemplo: CosTa, Storia del dirillo romano privalo. Dalle origini alle compilazioni giustinianee 2, Torino, 1925, p. 381, nt. I, segundo o qual, referindo-se o fr. I7 de D. 17,2 à sociedade universorum quale ex quaestu veniunt (assim como os demais fragmentos de Ulpiano extraídos do livro 30 ad $S a b$. , quais sejam, os frs. 7, 9 e 11 de D. 17,2), o valor que deve ser dado à expressão "uequales partes" deve ser o de proporcionalidade das quotas; Voci, Istituzioni di diritto romano3, Milano, 1954, p. 395; e Glück, Commentario alle Pandette, XVII (trad. italiana de Pacchioni e Cugia), Milano, $1904, \$ 966$, pp. 140-156, que afirma quotas proporcionais às conferições justamente porque existem reservas que condicionam o privilégio de um sócio a uma proporcional prestação de opera.

23. Cf. Cancelli, Società cit. (nota 21), pp. 501-502; Dernburg (com a colaboração de Bierınann), Pandette. Diritto delle obbligazioni6, II (trad. italiana de Cicala), Torino, 1903, \$ 126, p. 547, nt. 5.

24. Em Talamanca, Società in generale cit. (nota 20), p. 835, afirma-se ser essa solução um influxo do consortium ercto non cito, vez que nesse consórcio as quotas de participação entre os sui heredes não podiam ser diferentes. Em Arnò, ll contratto di società cit. (nota 4), pp. 189-190 (em que se acredita que a presunção de igualdade seria um prevalecimento da tese serviana, vez que o sócio de indústria é colocado em pé de igualdade com o sócio capitalista, e não da tese muciana, que contempla uına indústria mais preciosa que o capital), afirma-se que a solução teria sido influenciada pelo regime da societas ommium bonorum, cujas relações entre os sócios se baseiam no ius quodammodo fraternitatis, isto é, o patrimônio comum é dividido em partes iguais sem atentar para a qualidade e a quantidade das conferições de cada uın.

25. I. 3,25,3: "Illud expeditum est, si in una causa pars fuerit expressa, veluti in solo lucro vel in solo" dammo, in altera vero omissa: in eo quoque quod praetermissum est eandem partem servari." 
que imediatamente despontam são as seguintes: A proporção convencionada terá sempre eficácia? De todas as possiveis hipóteses, quais serão válidas e quais serão inválidas? ${ }^{26}$

Fugindo da paridade na repartição dos lucros e dos danos, pode-se pensar nas seguintes possibilidades: i. estabelecem-se quotas desiguais em harmonia com a desigualdade dos aportes; ii. estabelecem-se quotas desiguais não obstante a igualdade dos aportes; iii. fixam-se quotas desiguais para os lucros e quotas desiguais para as perdas, ou seja, repartem-se, para o mesmo sócio, os lucros de maneira diversa dos danos; iv. um sócio participa dos lucros, mas está isento de eventuais perdas; v. todos os sócios participam das perdas, mas só um dos sócios recebe todos os lucros; e vi. um dos sócios recebe todos os lucros estando isento das perdas. ${ }^{27}$ Ou ainda, em termos mais resumidos (reunindo em um mesmo item os itens "i." e "ii." supra e reunindo na mesma categoria "hipóteses extremas" os itens "iv." "v." e "vi." supra), configuram-se, em definitivo, as seguintes hipóteses de disparidade na repartição dos lucros e dos danos: ${ }^{28}$ i. quotas de lucros e perdas diferentes de um sócio para outro, porém iguais entre si para o mesmo sócio; ii. para um mesmo sócio, quota dos lucros diversa da quota das perdas; ou iii. as hipóteses extremas: a. atribuição ao sócio de uma quota dos lucros com total isenção das perdas; e b. atribuição de quota de perdas com total exclusão dos lucros.

O juízo a respeito de cada uma dessas hipóteses foi-se modificando ao longo do desenvolvimento da Jurisprudência, sempre em prol da autonomia dos contraentes, porém atravessado por tendências contrastantes. ${ }^{29}$ Afirma-se, inclusive, que o surgimento de um debate acerca desses problemas marca, historicamente, a emersão da consensualidade nas relações de associação, ${ }^{30}$ sendo que os textos em que se discutem as quotas de participação dos sócios nos lucros e nas perdas são ricos e instrutivos a respeito da evolução de certas concepções ético-sociais, em épocas clássica, pós-clássica e justinianéia. ${ }^{31}$

Foi no âmbito desta temática que surgiu, conforme se lembra em Gai. 3,149 , uma "magna quaestio" a respeito se pode subsistir um contrato de sociedade em que são diferentes, para o mesmo sócio, a quota de lucros e a quota de perdas.

A fim de captar a evolıção dos debates jurisprudenciais que se ocupavam desse problema, o trabalho prosseguirá com a exegese dos textos que o reportam ${ }^{32}$ :

26. Cf. Arnò, $/ l$ contratto di societì cit. (nota 4), p. 217.

27. Cf. Arnò, $l l$ comtratto di società cit. (nola 4), p. 2 I 8.

28. Cf. Arangio-Ruiz, La societì cit. (nota 1), p. 94.

29. Cf. Arangio-Ruiz, La società cit. (nota I), p. 94.

30. Cf. Cancelli, Società cit. (nota 21), p. 501.

31. Cf. Cancelli, Società cit. (nota 21), p. 502.

32. Os quatro textos que seguem, cerne do presente trabalho, são açompanhados de uma tradução em português. Para os textos de I. 3,25,2 e Gai. 3,149, faz-se uso da tradução sugerida em Correia e Sciascia, Manual de direito romano. Institutas de Gaio e de Justiniano vertidas para o português, em confironto) com o texto latino, II, São Paulo, 1951, pp. 197 e 545. Para os textos de D. 17,2,29,1 e D. 17,2.30, apresenta-se uma tradução livre. 
Gai. 3,14933 : Magna autem quaestio fuit, na ita coiri possit societas, ut quis maiorem partem lucretur, minorem damni praestet. Quod Quintus Mucius [...] etiam praevaluit sententia adeo ita coiri posse societatem existimavit, ut dixerit illo quoque modo coiri posse, ut quis nihil omnimo damni praestet, sed lucri partem capiat, si modo opera eius tam pretiosa videatur, ut aequum sit eum cum hac pactione in societatem admitti. Nam et ita posse coiri societatem constat, ut unus pecuniam conferat, alter non conferat, et tamen lucrum inter eos commune sit; saepe enim opera alicuius pro pecunia valet."

"Houve grande controvérsia sobre se se podia contrair sociedade com a cláusula de o sócio de maior co-participação nos lucros contribuir em parte menor para os prejuizos. O que Quinto Múcio [...] opinião prevaleceu, entendeu possivel mesmo em tal caso uma sociedade, dizendo pudesse ela constituir-se até de modo a um dos sócios não contribuir absolutamente para os prejuizos, recebendo entretanto parte dos lucros, desde que se lhe considere o trabalho tão precioso a ponto de ser eqüitativo admiti-lo à sociedade com este pacto. Pois, como é sabido, uma sociedade se pode constituir de modo a um dos sócios entrar e outro não, com dinheiro, dividindo-se entretanto os lucros entre eles; com efeito, muitas vezes o trabalho de alguém vale como dinheiro."

I. 3,25,2 $2^{34}$ : "De illa sane conventione quaesitum est, si Titius et Seius inter se pacti sunt, ut ad Titium lucri duae partes pertineant, damni tertia, ad Seium duae partes damni, lucri tertia, an rata debet haberi conventio? Quintus Mucius contra naturam societatis talem pactionem esse existimavit et ob id non esse ratam habendam. Servius Sulpicius, cuius sententia praevaluit, contra sentit, quia saepe quorundam ita pretiosa est opera in societate, eu eos iustum sit meliore condicione in societatem admitti: nam et ita coiri posse societatem non dubitatur, ut alter pecuniam conferat. alter non conferat, et tamen lucrum inter eos commune sit, quia saepe opera alicuius pro pecunia valet. Et adeo contra Quinti Mucii sententiam optinuit, ut illud quoque constiterit posse convenire, ut quis lucri partem ferat, damnu non teneatur, quod et ipsum Servius convenienter sibi existimavit. Quod tamen ita intelligi oportet, ut si in aliqua re lucrum, in aliqua damnum allatum sit, compensatione facta solum quod superest intellegatur lucri esse."

"Discute-se se se deve considerar válida a convenção seguinte: Tício e Seio acordaram entre si pertencessem a Tício duas partes de lucros e uma de prejuizos; e a Seio duas de prejuizos e uma de lucros. Quinto Múcio era de opinião

33. De Gai. 3,135 em diante se trata dos contratos consensuais, entre os quais se inclui a sociedade, especificamente considerada nos $\$ \$ 148-154$. Sobre as características do manual gaiano, v. Schipani, Le "Institutiones" di Gaio/Giustiniano, in IDEm, La codificazione del diritto romano comune, reedição, Torino, 1999, pp. $216-224$.

34. O título 3,25 das Institutiones de Justiniano é intitulado propriamente "De societate", sendo que os $\$ \$ 1$ 1-3 desse título lidam exclusivamente com o probleına da determinação das quotas de divisão dos lucros e das perdas. 
que um tal pacto era contra a natureza da sociedade e portanto não podia considerarse válido. Sérvio Sulpicio, cuja opinião prevaleceu, pensava, ao contrário, que muitas vezes o trabalho de certos, numa sociedade, é tão precioso que é justo admiti-los nela em melhor condição. Pois não há dívida se possa fazer uma sociedade, contribuindo um com dinheiro e outro, não, sendo entretanto comum o lucro entre eles, porque muitas vezes o trabalho de um vale tanto como dinheiro. E a tal ponto prevaleceu a opinião contrária à de Quinto Múcio, que também foi habitual poderse contratar que tenha um a parte do lucro, sem arcar com as perdas, opinião estimada justa pelo próprio Sérvio. Mas isso se deve entender no sentido de, havendo lucros num negócio e noutro, prejuizos, se considere lucro só o restante depois de feita a compensação."

Ulp. 30 ad Sab., D. 17,2,29,1: "Ita coiri societatem posse, ut nullam partem damni alter sentiat, lucrum vero commune sit, Cassius putat: quod ita demum valebit, ut et Sabinus scribit, si tanti sit opera, quanti damnum est: plerumque enim tanta est industria socii, ut plus societati conferat quam pecunia, item si solus naviget, si solus peregrinetur, pericula subeat solus."

"Opina Cássio que se pode constituir sociedade de modo a um não suportar nenhuma parte dos danos, e que o lucro seja comum; o que valerá, como também escreve Sabino, somente se o trabalho valer tanto quanto os danos; porque muitas vezes é tanta a indústria de um sócio, que confere à sociedade mais do que dinheiro; assim também se ele sozinho navegou, ou se ele sozinho viajou, ou se ele sozinho se expôs aos prejuizos."

Paul. 6 ad Sab., D. 17,2,30: "Mucius libro quarto decimo scribit non posse societatem coiri, ut aliam damni, aliam lucri partem socius ferat: Servius in notatis Mucii ait nec posse societatem ita contrahi, neque enim lucrum intellegitur nisi omni damno deducto neque damnum nisi omni lucro deducto: sed potest coiri societas ita, ut eius lucri, quod reliquum in societate sit omni damno deducto, pars alia feratur, et eius damni, quod similiter relinquatur, pars alia capiatur."

"Escreve Múcio no livro décimo quarto que não se pode constituir sociedade de modo a um sócio ter uma parte das perdas e uma outra dos lucros. Diz Sérvio nas notas a Múcio que tampouco se pode contrair sociedade dessa maneira; porque não se entende que exista lucro até deduzidas todas as perdas, nem perdas até deduzidos todos os lucros. Mas pode constituir-se sociedade de modo que dos lucros, que restam à sociedade, deduzidas todas as perdas, retire-se uma parte, e que das perdas, que igualmente resultam, sofra-se uma outra parte."

Em Gai. 3,149 (cuja ordem de idéias se completa com a segunda parte de Gai. 3,150) são consideradas as hipóteses sub "ii." e sub “iii., a." A discussão da hipótese em que o mesmo sócio tem a quota das perdas diversa da quota dos lucros apresentada nessa passagem permite que se alcance aquela outra hipótese em que o sócio participa dos lucros com isenção das perdas. Na passagem, dá-se uma resposta afirmativa a ambas as questões, com limitações, porém.

O primeiro problema de exegese que desponta nesse texto gaiano é o 
evidente erro cometido pelo amanuense do manuscrito veronês, que, depois do nome "Quintus Mucius", provavelmente saltou uma ou duas linhas do seu modelo graças à aliteração das palavras "Mucius" e "cuius" 35 Considera-se que a integração dessa lacuna está à mão porque em 1. 3,25,2, em que se apresenta o mesmo quesito considerado em Gai. 3,149 em termos só formalmente um pouco diversos, há a frase "Quintus Mucius contra naturam societatis talem pactionem esse existimavit, et ob id non esse ratam habendam. Servius Sulpicius, cuius sententia praevaluit" Ora, simplificando essa frase daquilo que pode ser alguma redundância bizantina, propõese e se aceita como provável expressão de Gaio o seguinte: "Quod Quintus Mucius contra naturam societatis esse existimavit. Sed Servius Sulpicius, cuius etiam praevaluit sententia", ${ }^{36}$ embora se reconheça ${ }^{37}$ não ser possível estabelecer o exato conteúdo e amplitude da lacuna.

Integração discutida, verifica-se em Gai. 3,149 e em 1. 3,25,2 que Quinto Múcio considerava inadmissível a diversidade, para um mesmo sócio, da quota de lucros e da quota de danos, pois ia "contra naturam societatis" 38 Sérvio Sulpício, por sua vez, afirmava o oposto, admitindo, até mesmo, excluir um sócio das perdas, mesmo

35. É tão evidente ser essa a causa da lacuna que é unanimemente admitida pela doutrina romanista, valendo mencionar, por exemplo: Arangio-Ruiz, La società cit. (nota 1), p. 95, nt. 1; Talamanca, Società in generale cit. (nota 20), p. 835, nt. 238; Bona, Studi sulla societì consensuale in diritto romano, Milano, 1973, p. 24, nt. 43; e Guarino, "Sociesas consensu contracta", in VV.AA., Atri dell'Accademia di Scienze Morali e Politiche della Società Nazionale di Scienze, Lettere ed Arti in Napoli, LXXXIII, Napoli, I972, pp. 283, nt. 69 [= "Societas consensu contracta". Quaderno n. 10 dell'Accademia di Scienze Morali e Politiche della Società Nazionale di Scienze Lettere ed Arti in Napoli, Napoli, 1972] [= in Idem, La società in diritto romano, Napoli, 1988, pp. 1-120].

36. Integração que consta de Arangio-Ruiz, La societì cit. (nota I), p. 95, nt. I. Essa é a integração majoritariamente propugnada pela crítica, também se propondo o verbo "censuit" no lugar de "existimavir" (para um balanço da literatura que tratou da integração dessa lacuna, v. Bona, Studi sulla società cit. (nota 35), p. 24, nt. 44). Contra essa integração, apresentou Rotondi, "Natura contracılus", in BIDR, 24, 19II, pp. 13-14, suspeitas formais, alegando ser caro aos justinianeus, poréın ignorado pelos clássicos, o conceito dogmático de natura contractus, que, portanto, teria sido usado nas /nstitutiones de Justiniano para se referir ao pensamento de Quinto Múcio sem que este tenha feito uso daquela expressão, vez que nĩo pensava em termos de natura societatis; em Gai. 3,149, portanto, ter-se-ia servido de alguma outra expressão para se referir ao pensamento de Quinto Múcio. A favor dessa tese de Rotondi, Pringsheim, “Natura contractus" und "natura actionis", in SDHI, I, 1935, pp. 78-80; contra, Guarneri-Citati, Conferimenti e quote sociali in diritto romano, in BIDR, 42, 1934, p. 175, nt. I. Comentando essa tese, Arangio-Ruiz, La società cit. (nota 1), pp. 95-96, afirına que se trata de suspeita meramente formal pois, ainda que se aceite a tese de Rotondi, mantém-se o fato de que em Gai. 3,149 se descreve um desenvolvimento da Jurisprudência republicana idêntico ao que se descreve nas lnstitutiones de Justiniano, ou seja, uma negação de Quinto Múcio contraposta por uma afirmação de Sérvio Sulpício, que, por fün, prevaleceu.

37. Assim Bona, Studi sulla societì cit. (nota 35), p. 24.

38. O pensamento de Quinto Múcio é reportado eın Gai. 3,149, segunda parte (integrada): "Quod Quintus Mucius contra naturam societatis esse existimavit"; em D. 17,2,30, parte inicial: "Mucius libro quarto decimo scribit nom posse societatem coiri, ut aliam damni, aliam lucri partem socius ferat"; e em 1. 3,25,2, segunda parte: "Quintus Mucius contra naturam societatis talem pactionem esse existimavit et ob id non esse ratam habendam" 


\section{fazendo-o participar dos lucros. ${ }^{39}$ Afirma-se, também, que a opinião de Sérvio "praevaluit". 40}

Afronta-se, agora, a questão a respeito de qual o sentido que deve ser dado à expressão "contra naturam societatis", atribuída a Quinto Múcio em I. 3,25,2 e em Gai. 3,149.41

Ainda que se considere superada a idéia de que o conceito de natura

39. O pensamento de Sérvio Sulpício é reportado em 1. 3,25,2, segunda parte: "Servius Sulpicius., cuius sententia praevaluit, contra sentit, quia saepe quorundam ita pretiosa est opera in societate, eu eos: iustum sit meliore condicione in societatem admitti: nam et ita coiri posse societatem nom dubitatu; ut alter pecuniam conferat, alter non conferat, et tamen lucrum inter eos commune sit, quia saepe opera alicuius pro pecunia valet"; e em Gai. 3,149, parte final: "Sed Servius Sulpicius ciuis etiam praevaluit sententia adeo ita corriposse socienuem existimavit, ut dixerit illo quoque modo coririposse, ut quis mihil omnimo dammi praestet, sed lacri partem capiat, si modo opera eius tam pretiosa videatu; ut aequum sit eam cum hac pactione in socieatem admithi. Nam et ita posse coiri societatem constat, ut anus pecuniam conferat, alter non conferat, et tamen lucrum inter eos commune sit; saepe enim opera alicuias pro pecunia valet". A exclusão total das perdas não é somente um desenvolvimento implícito e natural do pensamento serviano, mas foi assim formulada como conseqüência lógica (isto é, fundada na mesma ratio) do reconhecimento de uma participação nos lucros diversa daquela nas perdas.

40. Em sede de integração daquela lacuna em Gai. 3,149, apresenta Von Beseler tese que ataca a história da evolução das discussões jurisprudenciais sobre a determninação das partes lucri et damni. Com base em outros textos das fontes (D. 17,2,29,1 e D. 17,2,30), concluiu Von Beseler que a possibilidade de isenção das perdas não teria surgido com Sérvio Sulpício, mas com Cássio Longino, e a integração comumente aceita de Gai. 3,149 deveria ser substituída pela seguinte: "Quod Quintus Mucius et Servius Sulpicius negabant: Cassius autem, cuius etiam praevaluit sententia" (cf. Von Beseler, Zu Gaius 3,149, in SDHI, 4, 1938, pp. 205-207; e também IDEM, "Fruges et paleae" in Scritti in onore di Contardo Ferrini pubblicati in occasione della sua beatificazione, III, Milano, 1948, pp. 276-277). Contra essa tese, Di Marzo, "Pro Servio Sulpicio Rufo", in BIDR, 4, 1938, pp. 261-266; e também Arangio-Ruiz, La societì cit. (nota 1), pp. 96-100. Com relação ao texto contido em D. 17,2,29, 1, afirma Arangio-Ruiz que o fato de Cássio ter sido citado nessa passagemn nāo vale como atestado de que nenhum outro jurista antes dele alcançara a mesma conclusão. O que acontece é que, nas citações de autoridades, limita-se a recordar este ou aquele autor célebre sem remontar à primeira fonte da opinião em discurso. Ademais, em Gai. 3,149 não se pretendia estabelecer quem primeiro considerou válido o pacto de total isenção das perdas, mas estabelecer quem se opôs à categórica decisão de Quinto Múcio de que a quota dos lucros deveria ser necessariamente igual àquela das perdas. Por outro lado, continua Arangio-Ruiz, de D. 17,2,30 nāo se pode reconhecer uma eventual resistência de Sérvio Sulpício à isenção das perdas, conforme se conclui a partir da melhor exegese (infra) desse texto. Por último, o conteúdo de 1. 3,25,2, do qual não existem suspeitas, confirma que Sérvio Sulpício era de opiniāo oposta à de Quinto Múcio. Adiciona-se que a opinião de Von Beseler poderia ser admitida somente se houveșse qualquer prova de que o texto de 1. $3,25,2$ reportou, e por qual motivo, de modo incorreto a opinião de Sérvio Sulpício.

41. Ein D. 17,2,30, também se reporta o pensamento de Quinto Múcio no tema, mas em outros termos: admissibilidade ou nâo - "mon possie" - do pacto. Os dois modos de se exprimir não são incompatíveis e, portanto, dessa passagem não se pode concluir em senido contrário à at tribuição a Quinto Múcio da expressão contra naturam societatis, não se sabendo, ademais, se Paulo reportou o teor literal da expressão de Quinto Múcio (cf. Talannanca, La tipiciá dei contratti romani fira "conventio" $e$ "stipulatio" fino a Labeome, in Milazzo (coordenador), "Contractus" e "pactum" Tipicità e liberti negoziale nell'esperienza tardo-repubblicana. Atri del convegno di diritto romano e della presentazione della nuova riproduzione della "littera Florentina" Copanello 1-4 giugno 1988, Napoli, 1990, p. 70, nt. 137). 
contractus é estranho aos juristas clássicos, ${ }^{42}$ a incerteza a respeito da atribuição oulnão a Quinto Múcio daquela expressão afeta o valor daqueles textos como documentos dos quais se extrair noticias sobre o jurista republicano. De qualquer maneira, permanece o dado objetivo de uma discussão que em Gai. 3,149 e em I. 3,25,2 se visualiza sob o perfil da natura contractus, devendo-se excluir, até prova em contrário, que Gaio tenha entendido mal o pensamento de Quinto Múcio (sabe-se que Gaio conhecia diretamente os Libri iuris civilis de Quinto Múcio, tendo inclusive escrito um perdido comentário sobre eles, conforme consta em Gai. 1,188). ${ }^{43}$ Quinto Múcio, portanto, afrontava a temática do conteúdo de um contrato causal, cogitando, com base na função econômicosocial típica do contrato de sociedade, se determinadas cláusulas seriam admissíveis ou não. Ou seja, a expressão "contra naturam societatis", empregada em Gai. 3,149 e em I. 3,25,2 e talvez originária do próprio Quinto Múcio, não pretende dar relevo ao perfil da ilicitude do pacto, mas, sim, evidenciar a função econômico-social típica do contrato de sociedade. ${ }^{44}$

Outro problema é aquele das razões pelas quais Quinto Múcio não admitia a possibilidade de se fixar, para um mesmo sócio, partes lucri diversas das partes damni. Não é correto meramente supor que Quinto Múcio teria uma assim denominada concepção patrimonial da sociedade, ou seja, que não daria importância às conferições em opera e que negaria ao sócio de indústria uma posição paritária. ${ }^{45} \mathrm{Se}$ assim fosse, existiria entre sócio de capital e sócio de obra uma concreta diferença que se manifestaria, em termos práticos, com o primeiro podendo deduzir as próprias conferições em sede de liquidação e o segundo não o podendo. Não era assim que acontecia, porém, na sociedade romana, na qual primeiro se fazia a liquidação dos lucros e das perdas, o que acontecia no fím da gestão social, e só em seguida se aplicavam as partes lucri et damni ao resultado final de tal gestão, previamente calculado sem detração das conferições, sejam patrimoniais ou em serviços. O sócio de obra não se encontrava, portanto, em uma posição desprivilegiada, porque nem os serviços prestados nem os bens conferidos eram deduzidos em favor dos autores das conferições. ${ }^{46}$

Por outro lado, Quinto Múcio admitia a possibilidade de que as partes

42. Vide nota 36 supra.

43. Assim Talaınanca, La tipicitì cit. (nota 41), pp. 70-7I e nts. 136-138.

44. Cf. Talamanca, La tipicità cit. (nota 41), p. 71 e nt. 139.

45. Afirmam uma concepção patrimonial de Quinto Múcio: Wieacker, "Societas". Hausgemeinschafft und Erwerbsgesellschaft, I, Weimar, 1936, pp. 261-263; Bona, Studi sulla societì cit. (nota 35), pp. 26-28 e nt. 5I; e Kaser, Neue Literatur zur "societas", p. 314.

46. Cf. Talamanca, La tipicità cit. (nota 41), p. 71 e nt. 142; Idem, Società in generale cit. (nota 20), p. 836; Horak, "Rationes decidendi". Entscheidungsbegründungen bei den älteren rämischen Jurislen bis Labeo, I, Innsbruck, 1969, pp. 159-161. O fato de que na sociedade romana o ativo ou passivo liquido sobre o qual se aplicavam as pattes lucri et damni eram determninados sem a prévia de lução das conferiçōes, sejam em res, sejam em opera, faz perder sentido o discurso de que Quinto Múcio tinha unna concepção patrimonial da sociedade. 
lucri et damni variassem, desde que iguais entre si, de sócio para sócio, não existindo, por isso, motivos para pensar que pretendia impor rigorosos limites à autonomia das partes. Se, portanto, os socii não tivessem fixado as partes de modo proporcional às conferições de bens e serviços, nem mesmo Quinto Múcio, com toda a probabilidade, teria considerado inválido o pacto. Contra naturam societatis, segundo Quinto Múcio, era tão-somente o acordo em que se fazia uma explícita diversidade de tratamento entre os sócios, ou seja, aquela hipótese em que são díspares, para o mesmo sócio, a quota de lucros e a quota de perdas. A posição de Quinto Múcio, portanto, deve ser avaliada como voltada contra a expressa diversidade de condições entre os sócios, vez que socius, em sua visão, implica uma situação de igualdade e paridade, o que se macularia com um tratamento particular. ${ }^{47}$ e 48 É contra esta inaturalidade que se bate Quinto Múcio.

Mais do que os motivos de que se valeu Quinto Múcio para resistir a uma diferente quotização para o mesmo sócio, deve-se cogitar de quais fundamentos teria se servido Sérvio Sulpício para admitir, posteriormente, a não homogeneidade, para o mesmo sócio, entre a quota de lucros e a quota de danos. É muito provável que Sérvio Sulpício, constatando um dado freqüente da praxe econômica, qual seja, a associação entre sócio de capital e sócio de indústria (para fazer uso de uma terminologia moderna), tenha querido corrigir, nesse caso específico, com recurso à eqüidade (tão cara aos juristas republicanos), a natureza do contrato de sociedade, atenuando, sempre episodicamente, o rigor técnico-jurídico, sem o que poderiam se configurar situações não conformes à eqüidade. ${ }^{49}$

A contraposição entre Quinto Múcio e Sérvio Sulpício é atestada também em D. 17,2,30. A interpretação do exato teor dessa passagem é feita HoRAK ${ }^{50}$ e por Arangio-Ruiz ${ }^{51}$

47. Cf. Talamanca, La tipicitì cit. (nota 4I), pp. 7l-72 e nt. 143; e Cancelli, Societì cit. (nota 21), p. 502, nt. 3. É interessante nesse ponto também mencionar a idéia de Bremer, "Iurisprudentiae cuntehadrianae quae supersunt", I, Lipsiae, 1896 (reedição Leipzig, 1985), p. 95, segundo o qual Quinto Múcio teria sido hostil à quotização dos lucros diversamente das perdas porque isto contrastaria com a condição dos socii Italici, se foi ele o proponente da lex Licinia Mucia de 95 a.C.

48. Sobre o método de exposição do Direito de Quinto Múcio e a sua contribuição para a forınação do Direito (ius civile generatim constitutum, conforme se reporta em Pomp. ench., D. 1,2,2,41), v. Schipani, Le "Institutiones" di Gaio/Giustiniano cit. (nota 33), pp. 199-210. V., também, a reconstrução dos De iure civili libri de Quinto Múcio em Lenel, Palingenesia "iuris civilis", I, Graz, 1960, p. 758.

49. A predisposição dos juristas republicanos a defender a eqüidade, muitas vezes em detrimento do rigor jurídico, pode ser atestada em Cic. De or:, 1,56,239-240, em que se narra, em modo anedótico, um episódio em que o jurista Sérvio Galba oferece a um cidadão uma resposta em que justamente procede daquela maneira, ou seja, atenuando, dada uma situação específica, ensinamentos técnicos que constavam nos autores ("Galba autem adludens varie et copiose multas similitudines adferre multayue pro aequitate comtra ius dicere").

50. Horak, "Rationes decidendi" cit (nota 46), I, pp. 162-165.

51. Arangio-Ruiz, La società cit. (nota 1), pp. 97-98. 
À primeira vista, pode parecer que à negação de Quinto Múcio ("non posse societatem coiri") faz eco uma igual negação de Sérvio Sulpício ("nec posse societatem ita contrahi"). Porém, não deve ser essa a conclusão. Em primeiro lugar, a obra de Sérvio Sulpício aí mencionada, qual seja, os Notata Mucii, também chamada Reprehensa Scaevolae Capita, era explicitamente destinada à revisão de certas idéias do predecessor. ${ }^{52}$ Assim, não podendo Sérvio Sulpício ter concordado com Quinto Múcio, sugere-se que esse fragmento não captou mal o pensamento de Sérvio Sulpício, mas o comunicou mal. Na verdade, Sérvio Sulpício teria querido, com muita sutileza, observar que deveria ser verificado se Quinto Múcio pretendia negar a diferente quotização para cada uma das operações sociais individualmente consideradas ou se pensava na conta final de toda a atividade social. Segundo Sérvio Sulpício, se fosse a primeira hipótese, a desproporção realmente não era admissível, vez que as operações sociais individualmente consideradas são tomadas no seu conjunto, deduzindo-se as perdas dos lucros e vice-versa, e a opinião de Quinto Múcio, nesse sentido, seria banalmente óbvia. Mas, se fosse a segunda hipótese, isto é, se Quinto Múcio estivesse pensando na impossibilidade de diferente quotização mesmo no momento da divisão dos lucros e perdas totais entre os sócios, sua opinião não poderia prevalecer, devendo ser admitida a desproporção.

Ou seja, em D. 17,2,30, ao invés de uma concordância de Sérvio Sulpício com Quinto Múcio, está descrita a sua opinião acerca da necessidade de fazer, antes da aplicação concreta da quota de lucros ou da quota de danos, uma conta final dos lucros e das perdas de toda a gestão social, estando implícito nesse texto que Sérvio Sulpício admitia a extrema consequiência da total exclusão das perdas. É provável que Sérvio Sulpício tenha exposto essa idéia com mais precisão e elegância do que aquilo que está registrado no Digesto. ${ }^{53}$ Não é possível, porém, saber se o infeliz estado do texto de D. 17,2,30 deriva exclusivamente do modo muito resumido com que Paulo apresentou o pensamento de Sérvio Sulpício ou se funcionou a tendência dos compiladores justinianeus a reduzir ao mínimo a exposição das disputas jurisprudenciais.

De qualquer forma, a parte final de I. 3,25,2 ("quod tamen ita intelligi oportet, ut si in aliqua re lucrum, in aliqua damnum allatum sit, compensatione facta solum quod superest intellegatur lucri esse") põe termos precisos à discussão, pois aí se consigna que o lucro ou a perda que se deve levar em consideração para a aplicação das partes lucri et damni não é aquele de cada uma das operações sociais, mas, sim, aquele da conta final da gestão social, interpretação explicitamente indicada como a única aceitável da cláusula que dá a um sócio uma situação privilegiada.

Sérvio Sulpício, portanto, diante da manifestação de Quinto Múcio contrária à validade do contrato no qual as partes lucri fossem determinadas de modo diverso das partes damni, sustentava, por sua vez, que isso era possível até mesmo quando

52. V., a propósito, a reconsırução de Lenel, Palingenesia "iuris civilis", II, Graz, 1960, p. 323.

53. Essa explicação exclui que tenha havido interpolação em D. 17,2,30, conforme pretende Wieacker, "Societas" cit. (nota 45), pp. 263-264. 
um sócio fosse totalmente isentado das perdas, mesmo participando dos lucros. Sérvio Sulpício leva em conta o interesse dos outros sócios à aquisição da capacidade do sócio de indústria, permitindo que se privilegiasse esse último para o caso em que não tivesse meios para fazer frente às perdas patrimoniais que fossem além das perdas da opera prestada, o que o exporia a uma eventual condenação com base na actio pro socio. ${ }^{54}$

Pode-se indagar, também, quando finalmente teria prevalecido a opinião de Sérvio Sulpício. O desenvolvimento sucessivo sobre o tema pode ser hipoteticamente reconstruído através das formulações em Gai. 3,149 e em D. 17,2,29,1. É possível, também, que a opinião de Sérvio Sulpício tenha paulatinamente prevalecido, porque os juristas sucessivos adeptos da teoria serviana a ela tenham aposto algumas ulteriores elucidações, limitações e condições. ${ }^{55}$ De qualquer forma, provavelmente com Sabino e Cássio a validade do pacto de participação nos ganhos em medida diversa das perdas e também do pacto de exclusão das perdas a favor do sócio de obra foi definitivamente acolhida. ${ }^{56}$

Tendo prevalecido a opinião de Sérvio Sulpício (rectius: à medida que vai prevalecendo), surge, então, o problema dos limites em que era admitida, para o mesmo sócio, a diversidade das partes lucri et damni, controvérsia em torno da qual se reuniram os juristas sucessivos.

Ora, em Sérvio Sulpicio e na Jurisprudência sucessiva, a diversidade entre a pars lucri e a pars damni está geralmente ligada à avaliação do particular valor da obra conferida pelo sócio privilegiado. Assim, discutir os limites da diversidade das partes lucri et damni significa discutir se a obra merecia uma avaliação autônoma com relação ao capital, e mais do que isso, os termos e condições dentro dos quais deveria se limitar uma tal avaliação. ${ }^{57}$

54. Cf. Talamanca, La tipicità cit. (nota 41), p. 74; Idem, Società in generale cit. (nota 20), p. 836.

55. Essa é a sugestão de Arnò, Il contratto di societì cit. (nota 4), pp. 232-235. Segundo Arnò, seriam adeptos da teoria serviana Sabino, Cássio, Gaio, Paulo e os compiladores justinianeus. No entanto, a opinião de Arnò, deve ser vista com cautela porque ele não suspeita de eventuais intervenções pós-clássicas ou justinianéias nos textos que reportam o prosseguimento dos debates.

56. Cf. Bona, Studi sulla societì cit. (nota 35), p. 33. Não se deve esquecer que em Gai. 3, 149 a quacstio e a aceitação da tese serviana são narradas no passado, com "fuit" e "pratevaluit"

57. Cf. Talamanca, Societc̀ in generule cit. (nota 20), p. 836; e também Bona, Studi sulla societì cit. (nota 35), p. 29. Afirma-se que a constante inenção, tanto em Gai. 3, I49 como em D. 17,2,29, I, ao binômio "pecunia"-"opera" leva a concluir que a controvérsia em questão não nasceu com relação a todo tipo de sociedade, mas apenas com relação à sociedade em que um sócio versa o capital e o outro a obra necessária para a empresa, ou seja, à societas qualestus (cf. Bona, Studi sulla societì cit. (nota 35), pp. 26 27. Menos radical em Idem, Contributi alla storia della "socielas universorum quae ex questu veniunt" in diritto romano, in Studi in onore di Giuseppe Grosso, I, Torino, 1968, p. 448 e nt. 104, apontando-se que a discussão teria surgido justamente no tempo emn que a geração de Quinto Múcio e Sérvio Sulpício estava empenhada na construção da disciplina jurídica típica da societas quaestuis, não sendo claro porém se a discussão se limitou ao âınbito dessa sociedade, emn que a freqüência de contribuições heterogêneas - pecunia e opera - contribuía para o debate, ou se também se alargou à sociesas omnium bonorum.). Objeta-se tal idéia porque ela iria ınuito além das palavras de Gaio, que atribui a Quinto Múcio e Sérvio Sulpício uma magna quaestio em tema de societas e nada mais, de modo que nem Quinto Múcio nem Sérvio Sulpício, muito menos Gaio, jurista do séc. II d.C., teriam excluído a societas omnium bonortum da 
Para que se estabeleça o nexo entre a opera prestada e o privilégio atribuído ao sócio de obra, existem as seguintes vias: i. os próprios contratantes fazem a avaliação do valor da obra prestada pelo sócio de indústria, aceitando-se essa avaliação; ii. essa avaliação feita pelos contratantes deve ser submetida a um controle ex post, com base na situação existente no momento da conclusão do contrato; ou iii. o controle ex post da avaliação feita pelos contratantes deve considerar o concreto desenvolvimento da gestão social. ${ }^{58}$

O problema da aposição de condições à determinação não homogênea das partes lucri et damni (e também das condições ao pacto de exclusão das perdas) desponta, mor das vezes, como um juízo da avaliação que os contratantes fizeram da opera prestada pelo sócio privilegiado. Esse problema é narrado em Gai. 3,149, I. $3,25,2$, e D. 17,2,29, 1, cada uma das passagens oferecendo diversas orientações - quem, quando e como - a serem obervadas quando do juízo daquela avaliação. ${ }^{\text {(") }}$

Segundo a narrativa em I. 3,25,2, para Sérvio Sulpício são as partes que avaliam, no momento da conclusão do contrato, a relação entre a preciosidade da obra e a isenção das perdas, sendo esse o significado que se deve dar às palavras "quia saepe quorundam ita pretiosa est opera in societate, ut eos iustum sit meliore condicione in societatem admitti". Ou seja, Sérvio Sulpício admitiria, em qualquer caso, a relevância da opera do socius, bastando que se estabelecesse, em sede contratual, se e quanto ela vale. Essa solução, portanto, coincide com a hipótese sub “i.", pois se admite a avaliação feita pelos sócios da obra prestada pelo sócio privilegiado, sem qualquer espécie de controle ex post, consagrando-se a autonomia das partes. ${ }^{60}$

Em Gai. 3,149, todavia, afirma-se que Sérvio Sulpício teria subordinado a relevância da opera do socius à condição, a ser verificada em juízo, de que seja particularmente "pretiosa": "si modo opera eius tam pretiosa videatur, ut aequum sit eum cum fac pactione in societatem admitti" Ou seja, o pensamento de Sérvio Sulpício a respeito da avaliação da opera do sócio está, agora, coincidindo com a hipótese sub "ii."

Embora o texto de I. 3,25,2 (em que o pensamento de Sérvio Sulpício se coaduna com a hipótese $s u b$ "i."), seja formalmente muito semelhante ao texto de Gai.

discussão (cf. Guarino, "Societas consensu comuracta" cit. (nota 35), pp. 282-284). Tal objeção de Guarino parte da premissa, por ele sustentada, de que Gajo não considerava a societas omnium bonorum uma sociedade universal unicamente de mero gozo, mas uma sociedade universal também de indústria, sendo que a societas omnium bonorum teria se configurado de mero gozo somente em época pós-clássica, no quadro da decadência geral da economia romana.

58. Assim se apresentam em Talamanca, Società in generale cit. (nota 20), p. 837.

59. Segundo Guarino ("Societas consensu contracta" cit. (nota 35), pp. 289-292), não teria havido divergência entre os jurisprudentes romanos quanto ao juízo que deveria ser feito sobre a avaliação da obra a ser prestada pelo sócio privilegiado, sustentando que os textos de Gai. 3,149, D. 17,2,29, J e I. 3,25,2 querem dar a mesına solução. Dessa idéia discorda Talaınanca, Società in generale cit. (nota 20), p. 837 e nt. 234.

60. Cf. Talannanca, Società in generale cit. (nota 20), p. 837 e nts. 251 e 252; e Guarino, "Societas consensu contracta" cit. (nota 35 ), p. 289 , nt. 85 . 
3,149 (em que o pensamento do mesmo jurista se coaduna com a hipótese $s u b$ "ii."), existem entre ambos muitas diminutas divergências, ou seja, há frases que se assemelham, mas que, nas minúcias, contradizem-se. As divergências que se evidenciam nos textos de Gaio e de Justiniano ocorrem por causa das características da Jurisprudência na época clássica e nas épocas sucessivas.

Aquele primeiro manual (Institutiones de Justiniano) discorre sobre as razões pelas quais as partes podem ser induzidas a variar as proporções: constatandose que as circunstâncias podem justificar a desigualdade de tratamento, considera-se absolutamente válida a cláusula que admite tal desigualdade. $\mathrm{O}$ "si modo" presente nas Institutiones de Gaio, ao contrário, corresponde a um "contanto que" ou "desde que" transformando o particular valor da colaboração do sócio numa condição de validade da cláusula, à qual o juiz da actio pro socio poderia negar aplicação, quando se convencesse que a condição não se fazia presente. ${ }^{61}$

Observa-se, portanto, um contraste entre o ponto de vista da Jurisprudência clássica e o ponto de vista de um período posterior. Tratando-se de um conflito entre uma passagem das Institutiones de Gaio e uma das Institutiones de Justiniano, imediatamente veín à mente a idéia de que o pensamento clássico estaria registrado na obra de Gaio, enquanto nas Institutiones de Justiniano se exprimiriam idéias pós-clássicas. ${ }^{62}$ Arangio-Ruiz, porém, afirma que, por curioso proceder da tradição manuscrita, a solução que prevaleceu na Jurisprudência clássica foi expressa nas Institutiones de Justiniano, vez que os compiladores teriam tido uma edição das Institutiones de Gaio estritamente conforme o original, e assim puderam reportar a correta opinião de Gaio. No manuscrito veronês, ao contrário, sustenta ainda ArangioRuiz, interveio a mão de um estudioso pós-clássico que quis limitar as desigualdades entre os sócios, não a admitindo senão sob o controle do juiz. ${ }^{63}$

61. Arangio-Ruiz, La società cit. (nota 1), pp. 100-101. Afirma Arangio-Ruiz que não vale dizer, a fim de tentar superar essa divergência, que a proposição das Institutiones de Justiniano se refere à simples diferença das quotas, enquanto aquela de Gaio se refere à total isenção das perdas. Na ordem de idéias da Jurisprudência, a isenção das perdas diferia da diversa quotização somente quantitativamente, sendo, na verdade, uma extrema aplicação do mesmo critério basilar.

62. Assim Di Marzo, "Pro Servio Sulpicio Rufo” cit. (nota 40), p. 265; e também Guarneri-Citati, Conferimenti e quote sociali cit. (nota 36), p. 177.

63. Arangio-Ruiz, La società cit. (nota 1), pp. 101-104. Essa opiniāo de Arangio-Ruiz advém: i. da coerência entre I. 3,25,2 e as passagens do Digesto (D. 17,2,29,1 e 30); e ii. das diferentes posições com relação à autonomia das partes no contrato consensual que têm o pensamento clássico e pós-clássico. De fato, o respeito à autonomia contratual é ınáximo na antiga jurisprudência, enquanto o pensamento da decadência tende a proteger a parte que, por causa da habilidade da outra, sofre uma lesão patrimonial. A pretensão de que a desproporção entre a quota dos lucros e a quota das perdas, expressamente querida pelas partes, deve ser oportunamente controlada pelo juiz se inspira nessa última ordem de idéias. Ou melhor, exaspera-a, porque não é possível controlar o valor da opera que os contratantes, com antecedência (isto é, antes e sem levar em conta a efetiva prestação do serviço), apenas previram ou supuseram, de modo que o juiz acaba confundindo o juízo sobre a suposição dos contratantes com a avaliação dos resultados efetivaınente alcançados. Assim, na prática, nega-se qualquer aplicação da cláusula que teria 
Por seu turno, em D. 17,2,29,1, texto que constitui um excelente campo de observação a respeito do prosseguimento dos debates, Sabino ${ }^{64}$ e Cássio ${ }^{65}$ parecem condicionar o acordo a uma equivalência entre o dano do qual o sócio é exonerado e a preciosidade da obra, a ser avaliada no momento da liquidação final mas se levando em consideração a efetiva contribuição do sócio de opera durante a gestão social (hipótese sub "iii."). O fragmento, porém, é pouco confiável, dado que o seu atual teor é devido, com muita probabilidade, a uma abreviação feita pelos compiladores. A abreviação se evidencia pelo fato de que, em uma obra como os comentários ad Sabinum de Ulpiano, é improvável que a quaestio fosse repassada sem que se recordasse o contraste entre Quinto Múcio e Sérvio Sulpício. Os compiladores, portanto, teriam intervindo suprimindo o articulado balanço que Ulpiano teria feito da controvérsia, do que deriva a atual textura comprimida e incompleta do texto. ${ }^{66}$

A suspeita de interpolação em D. 17,2,29,1 aumenta na medida em que alguns dos seus trechos também limitam a autonomia das partes em caso de desigualdade entre lucros e perdas (o que não se coaduna com o pensamento clássico ao qual se filia Ulpiano): "quod ita demum valebit" e "si tanti sit opera, quanto damnum est". Essa circunstância oferece grande dificuldade ao juiz, que deve verificar, em caso de perda, se a colaboração do sócio isento das perdas foi tão preciosa a ponto de justificar o privilégio. A condição a que se sujeita a validade da isenção das perdas aparece impraticável: "si tanti sit opera, quanto damnum est" isto é, se o valor da contribuição do sócio é igual ao valor da perda sofrida. Dado o prejuizọ, o juiz, que julga ex eventu, chegará, na maior parte dos casos, à conclusão de que o valor daquela opera é zero, e atribuirá a perda também ao sócio que seria isento. Todavia, ainda existiria a possibilidade de aplicação do pacto de exclusão quando as perdas fossem derivadas de causa ou força maior. A intervenção em D. 17,2,29,1 é certamente pré-

dado a um dos sócios uma posição privilegiada. Os compiladores justinianeus, ao menos nessa parte do Corpus iuris civilis, cancelaram a tirânica pretensão equilibrista e paternalista da jurisprudência bizantina, retornando ao ensinamento dos clássicos. Concluir pela intervenção pós-clássica em Gai, 3,149 poderia parecer mera conjectura não fossem outras afirmações igualınente limitadoras da liberdade contratual encontradas em outras passagens gaianas manifestamente glosadas em época pós-clássica. Tal acontece em Gai. 3,150, em que se discute uma questão logicannente anterior àquela da possibilidade de se excluir um sócio das perdas, qual seja, a liberdade de se fixar quotas diversas entre os sócios desde que iguais nas perdas e nos lucros: essa passagem de Gaio limita a vontade das partes ao afirmar que, quando nada tenha sido disposto a respeito, presume-se a igualdade das quotas, sendo apenas implícita a admissibilidade de uma quotização diversa, sendo provável que o genuíno pensamento de Gaio nāo tenha sido por ele assim expresso. Ao contrário, tal admissibilidade é explicitamente declarada em 1. 3,25,2, o que comprova o posicionamento das Institutiones de Justiniano junto às idéias clássicas.

64. A propósito do reportamento, nessa passagem do Digesto, do pensainento de Sabino, v. Lenel, Palingenesia "iuris civilis" II cit. (nota 52), p. 197, para a disposição original da obra do jurista.

65. No mesmo sentido da nota anterior, agora a respeito do jurista Cássio, v. Lenel, Palingenesia "iuris civilis" I cit. (nota 48), p. 114.

66. Cf. Talananca, Società in generale cit. (nota 20), p. 837 e nt. 254. 
justinianéia, pois há contraste com o pensamento dos compiladores na correspondente passagem das Institutiones de Justiniano. ${ }^{67}$ e 68

Por fim, vale traçar algumas considerações a respeito daquela hipótese em que um sócio é totalmente excluído dos lucros. A hipótese sequer foi objeto de discussão entre os juristas. Informa-se em Ulp. 30 ad Sab., D. 17,2,29,2, ${ }^{69}$ que se tratava de "iniquissimum genus societatis", tendo chamado-a Cássio, segundo Aristão, "societas leonina", numa óbvia referência a Fedr. 1,5.70 Concretamente, essa passagem

67. Cf. Arangio-Ruiz, La società cit. (nota 1), pp. 108-109. A boa exegese de D. 17,2,29,1 feita por Arangio-Ruiz, com a constatação de intervenção pós-clássica, afasta aquela idéia de Bona (Studi sulla società cit. (nota 35), pp. 31-34), que, buscando captar a linha das diferentes opiniões dos juristas clássicos a respeito dos limites à livre determinação das partes e à avaliação, por partes dos sócios, do valor da opera do sócio de indústria, acaba caindo naquilo que Guarino, "Societas consensu contracta" cit. (nota 35), p. 290, chama de "ondeggiamento" de pensamento.

68. A mesına ordem de idéias, ou seja, umna intervenção pós-clássica tendente a uma limitação da autonomia dos contratantes, também se aplica, segundo Arangio-Ruiz, La societì cit. (nota 1), pp. 104 108, à passagem em D. 17,2,29 pr., que trata da disparidade de quotas entre sócios, mas idênticos os lucros e as perdas para cada sócio. O texto, também fazendo uso do "si modo", afirına que tal convenção pode valer somente se o juiz constatar que existiam no momento do contrato elementos que justificavam a diversidade do tratamento e, onde tais elementos não existissem, deveria proceder à liquidação com base na igualdade das quotas. Não se pode, simplesmente, concluir pela interpolação justinianéia de toda aquela parte do texto que começa com "si modo" assim Guarneri-Citati, Conferimenti e quote sociali cit. (nota 36), pp. 185-187), pois uma tal conclusão é inconciliável com a passagem das Institutiones de Justiniano que proclama incondicionalmente a licitude do pacto. Daí, considera-se que o contraste entre a passagem de D. 17,2,29 pr. e o ensinamento da jurisprudência clássica é devido a uma glosa inserida em época pós-clássica no texto de Ulpiano por um estudioso afim às idéias moralistas de equivalência das prestaçōes. Os justinianeus, neste tema, como as Institutiones demonstram, não seguiram a corrente de pensamento pós-clássica e teriam evitado reproduzir o texto do fr. 29 pr. assiin glosado. Porém, não teriam ousado cancelar reservas que pareciam ditadas por Ulpiano. Então, empenharam-se em torná-la inócua com uma ulterior colocação de uin novo trecho, qual seja, aquela última parte "vel cuiuscumque alterius rei causa". A rigor, uına verdadeira limitação da autonomia das partes está contida somente na parte "si modo aliquid plus contulit societati pecuniae vel operae". O trecho "cuiuscumque alterius rei causa" é de tal modo vago que um juiz acharia difícil negar aplicação ao pacto: se as partes atribuíram a um ou mais sócios quotas diferentes, isto sempre se deve a qualquer motivo. Ademais, estas palavras não dependem gramaticalmente nem de "plus contulit" nem diretamente da conjunção "si modo". Conclui-se, portanto, que o fr. $29 \mathrm{pr}$. resulta da superposição de três mãos: i. aquela do jurista clássico, que, afirmando a validade em todo caso da disparidade das quotas (contanto que fossem iguais nos lucros e nas perdas), fechava com as palavras "placet valere"; ii. aquela de um anotador pós-clássico, que pretendeu limitar a autonomia das partes pedindo como justificação da disparidade de quotas uma correspondente disparidade nos capitais ou na indústria conferida; e iii. aquela dos compiladores justinianeus, os quais, pretendendo afirmar nesse tema a autonomia das partes, praticamente cancelaram, com as últimas cinco palavras, a aplicação das reservas insinuadas no texto de Ulpiano.

69. Ulp. 30 ad Sab., D. 17,2,29,2: "Aristo refen Cassium respondisse socientum talem coiri non posse, ut alter lucrum tantum, alter damnum sentiret, et hanc societatem leoninam solitum appellare: et nos consentimus talem societatem nullam esse, ut alter lucrum sentiret, alter vero nullum lucrum, sed damnum sentiret: iniquissimum enim genus societutis est, ex qua quis damnum, non etiam lucrum spectet."

70. Trata-se da fábula da associação entre o leão, a vaca, a cabra e a ovel ha com o escopo de caçar o cervo. Porém, terminada a caça, o leão toma para si o produto do esforço comum, de modo que os outros animais tenham participado somente do risco da atividade. Assim a redação latina de Fedr. 1,5: "Numquam 
mostra que, diante dos desenvolvimentos da teoria serviana, Cássio sentiu a necessidade de uma tomada de posição, o que não significa que qualquer dos prudentes tenha cogitado a validade da societas leonina. ${ }^{71}$

\subsection{A determinação das quotas de lucros e de danos a encargo de um dos sócios ou de um terceiro.}

Por fim, apresenta-se aquela via pela qual a determinação das quotas de cada sócio nos lucros e nas perdas é deixada a cargo de um terceiro ou a cargo de um dos próprios sócios. Trata-se de uma ampliação do tema que será, aqui, tão-somente mencionada. ${ }^{72}$

Se o árbitro designado é um dos próprios sócios, o texto essencial é Pomp. 9 ad Sab., D. 17,2,6. ${ }^{73}$ Quando, porém, o árbitro designado é um estranho, é essencial a cadeia de textos que vai de D. 17,2,76 a 80 .

A questão é solucionada em Próc. 5 epist., D. $17,2,76^{74} 78^{75}$ e $80^{76} \mathrm{O}$

est fidelis cum potente societas: testatur haec fabella propositum mean. Vacat et capella et patiens ovis iniuriae socii fuere cum leone in saltibus. Hi cum cepissent cervum vasti conporis, sic est locutus portibus factis leo: ego primam tollo nomine hoc quia rex cluo; secundam, quia sum consors, tribuetis mihi; tum, quia plus valeo, me sequetur tertia: malo adficietur si quis quartam tetigerit. Sic tolam praedam sola improbitas abstulit."

7I. Cf. Talamanca, Società in generale cit. (nota 20), pp. 835-836; e também Arangio-Ruiz, La società cit. (nota 1), pp. 110-111; para um tratamento específico, remete-se a Guarino, La societì col leone, in Idem, La societù cit. (nota 35), pp. 175-192.

72. Para uma compreensão mais aprofundada do problema, remete-se a Arnò, ll contratuo di societì cit. (nota 4), pp. 195-218; Cancelli, Societa cit. (nota 21), pp. 502-503; Gallo, La dottrina di Proculo e quella di Paolo in materia di arbitraggio, in Studi in onore di Giuseppe Grosso, III, 1969, pp. 479-542; e Arangio-Ruiz, La societì cit. (nota I), pp. III-115.

73. Pomp. 9 ad Sab., D. 17,2,6: "Si societatem mecum coieris ea condicione, ut partes societatis constitueres, ad boni viri arbitrium ea res redigenda est: et conveniens est viri boni arbitrio, ut non utique ex aequis partibus socii simus, veluti si alter plus operae industriae pecuniate in societatem collaturus sit."

74. Próc. 5 epist., D. 17,2,76: "Societatem mecum coisti ea condicione, ut Nerva amicus communis partes societatis constitueret: Nerva constituit, ut tu ex triente socius esses, ego exbesse: quaeris, utrum ratum id iure societatis sit, an nihilo minus ex aequis partibus socii simus. existimo autem melius te quaesiturum fuisse, utrum ex his partibus socii essemus quas is constituisset, an ex his quas virum bonum constituere oportuisset. arbitrorum enim genera sunt duo, unum eiusmodi, ut sive crequum sit sive iniquum, parere debeamus (quod observatur, cum ex compromisso ad arbitrum itum est), alterum eiusmodi, ut ad boni viri arbitrium redigi debeat, etsi nominatim persona sit comprehensa, cuius arbitrutu fĩat."

75. Próc. 5 epist., D. 17,2,78: "in proposita autem quaestiome arbitrium viri boni existimo sequendum esse, eo magis quod iudiciunt pro socio bonae fidei est."

76. Próc. 5 epist., D. 17,2,80: "Quid enim si Nerva constituisset, ut alter ex millesima parte, alter ex duo millesimis partibus socius esset? illud potest conveniens esse viri boni arbitrio, ut non utique ex aequis partibus socii simus, veluti si alter plus operae industriae graticte pecuniae in societutem collaturus erat." 
jurista expõe que não se pode examinar um tal problema, sob o seguinte ponto de vista: ou certa determinação do terceiro de conferir para um maior participação nos lucros do que para outro é válida ou se procede como se nada tivesse sido estabelecido e se consideram cotas iguais. Propõe o jurista que, diante de uma questão nesse tema, devese atuar da seguinte maneira: ou é válida certa determinação ou se reparte conforme determinaria um homem justo (critério do arbitrium boni viri). Aqui se traça uma doutrina geral dos poderes do terceiro escolhido como arbiter (no senso mais geral da expressão), encarregado de decidir um conflito de interesses. Ou seja, discute-se se o árbitro tem ou não um poder discricionário e não controlável. Tal poder existe se o árbitro é investido por um compromisso idêntico àquele que o magistrado romano confere ao iudex para decidir uma determinada controvérsia. Onde não exista um tal poder discricionário, a atividade do encarregado está sujeita a eventual controle do juiz, ao qual cabe definir se aquele agiu segundo os critérios fundamentais do bonum et aequm, e, caso negativo, decidir com base nesta medida, não sendo possivel a mera redução das quotas à igualdade. ${ }^{77}$

Se o árbitro não quiser ou não puder determinar as quotas, então não se formará a sociedade, conforme se relata em Cels. 15 dig., D. 17,2,75. ${ }^{78}$

\section{A Jurisprudência tardo-republicana.}

O tema da determinação das partes lucri et damni oferece uma boa oportunidade para o estudo das características e do desenvolvimento da Jurisprudência republicana, sobretudo a Jurisprudência tardo-republicana, em que se localizavam Quinto Múcio e Sérvio Sulpício.

\subsection{Os principais jurisconsultos republicanos. ${ }^{79}$}

Pompônio, em longo fragmento (D. 1,2,2,35 ss.) oferece a sucessão de jurisconsultos republicanos. Destacam-se três figuras da segunda metade do segundo século: Públio Múcio Cévola (cônsul em 133 a.C. e depois pontífice máximo), Marco Júnio Bruto (pretor em 142 a.C.) e Marco Manílio (cônsul em 149 a.C.), os quais são apresentados como aqueles que "fundaverunt ius civile"

No entanto, afirma-se que os dois maiores juristas da época republicana foram Quinto Múcio Cévola e Sérvio Sulpício Rufo.

Quinto Múcio Cévola foi cônsul em 95 a.C., depois pontífice máximo, tendo sido assassinado pelos soldados de Mário em 82 a.C. Tentou uma reconstrução

77. Cf. Arangio-Ruiz, La società cit. (nota 1), pp. 112-115.

78. Cels. 15 dig., D. 17,2,75: "Si societutem mecum coieris ea condicione, ut partes societatis constitueres, ad boni viri arbitrium ea res redigenda est: et conveniens est viri boni arbitrio, ut non utique ex aequis partibus socii simus, veluti si alter plus operae industriae pecuniae in societatem collaturus sit."

79. Cf. Grosso, Lezioni di storia del diritto romano5, Torino, 1965, pp. 297-300. 
sistemática do Direito. ${ }^{80}$ Pompônio diz dele: "ius civile primus constituit generatim in libros decem et octo redigendo". Estes dezoito livros iuris civilis se tornaram uma obra fundamental de sistemática e constituíram a base para os sucessivos tratamentos, tanto que três jurisconsultos do séc. II d.C., Lélio Felice, Gaio e Sexto Pompônio, escreveram livros de Direito Civil comentando essa obra (libri ad Quintum Mucium). Outra obra de Quinto Múcio, liber singularis sive definitionum, chegou ao tempo de Justiniano, dele extraindo os compiladores alguns fragmentos para o Digesto. De Quinto Múcio se recordam alguns discípulos: Aquílio Galo (o mais célebre, lembrado pelo fecundo desenvolvimento concreto do Direito, sendo a ele atribuída a criação do iudicium de dolo e da stipulatio Aquiliana), Balbo Lucílio, Sexto Papírio e C. Juvêncio.

Diante de Quinto Múcio e da sua escola se ergue um outro grande jurisconsulto, Sérvio Sulpício Rufo, cônsul em 51 a.C. e morto em 43 a.C. Amigo de Cícero e por ele exaltado, homem de ampla cultura, inclusive filosófica, famoso orador, ressonante na Jurisprudência do principado. Pompônio diz que ele deixou cerca de 180 livros, dos quais alguns ainda conhecidos e consultados nos seus tempos, isto é, sob os Antoninos. Guiado nos estudos por Balbo Lucílio e por Galo Aquílio, torna-se opositor de Quinto Múcio, tendo muita difusão uma sua obra intitulada Notata Mucii ou Reprehensa Scaevolae capita.

Pompônio recorda como auditores de Sérvio Sulpício dez jurisconsultos. Os dois mais célebres são Aulo Ofilio e Alfeno Varo. O primeiro, amigo de César, teria escrito alguns livros de iure civile, uma obra de legibus e uma outra sobre o edito pretoriano. Alfeno Varo deixou os Digesta, de quarenta livros, dos quais os compiladores justinianeus tiveram nas mãos dois extratos, sendo conservados no Digesto alguns dos seus fragmentos: nestas passagens se conserva uma direta amostra da Jurisprudência dessa época e da viva elaboração e criação do Direito. A eles se seguiram Aulo Cascélio e Trebácio Testa, e depois Quinto Élio Tuberão, chegando-se ao limiar da Jurisprudência do principado.

\subsection{A atividade da Jurisprudência e a sua contribuição para a formação do Direito. ${ }^{81}$}

A sucessão de nomes apresentada por Pompônio compõe um horizonte de três séculos. No início, a atividade do jurista laico seguia aquela da Jurisprudência pontifical, resumindo-se nos três verbos: cavere (no âmbito dos negócios, preparação de esquemas idôneos a alcançar os escopos queridos pelos consulentes), agere

80. A respeito de Quinto Múcio, Pomp. ench, D. 1,2,2,43, narra curioso diálogo que também envolveu o então jovem Sérvio Sulpício, o qual, não compreendendo uma resposta a uma consulta feita a Quinto Múcio, foi severamente repreendido por este. O episódio, descrito em termos anedóticos, tem profundo valor simbólico e traz indicações a respeito de um estilo de vida: demonstra-se como a jurisprudência republicana apregoava, fazendo uso da eloqüência, que se observasse um comportamento público exemplar ("ita obiurgatum esse a Quinto Mucio: namque eum dixisse turpe esse patricio et nobili et causas oranti ius in quo versaretur ignorare"). A propósito dessa passagem de Pompônio, v. Bretone, Storia cit. (noti 12), pp. 168-170.

81. Cf. Grosso, Leziomi cit. (nota 79), pp. 300-303. V., também, sobre as características da jurisprudência republicana, Bretone, Storia cit. (nota 12), pp. 153-194; e Schulz, pp. . 
(assistência na escolha e na adaptação das fórmulas processuais, tarefa distinta da defesa da parte perante o juiz, normalmente assumida pelo orator, treinado na arte da retórica) e respondere (oferecimento de um parecer sobre uma fattispecie apresentada, tarefa que especificamente envolve a solução dos problemas controversos do Direito).

Os juristas pertenciam à nobilitas e faziam carreira política. Gozavam de altíssima consideração da opinião pública. À sapiência jurídica se unia a retidão moral, e a figura do jurista tornou-se entre os romanos alto termo de referência moral.

A consulta era pública e gratuita. O conhecimento do Direito era honroso para a aristocracia, e aos consulentes se uniam discípulos desejosos de aprender. Os escolares seguiam os maestros, tomavam notas e depois propunham casos. Assim, da consulta nascia a discussão e o ensinamento. A primeira atividade literária deve ter sido constituida de coleções de respostas de cautiones ou de actiones.

A chegada a Roma da cultura grega levou à obra da Jurisprudência o método dialético e, portanto, a verdadeira e própria elaboração científica. Etapas de desenvolvimento podem ser marcadas: da exteriorização da analogia dos casos, a aplicação da dialética conduz à formação de regulae; destas, procede-se à formação do sistema, e assim da Jurisprudência cautelar se passa à cientifica.

A elaboração do ius civile se deve, portanto, ao desenvolvimento da Jurisprudência. $O$ antigo ius civile se movimenta e se desenvolve por meio de cisões e unificações. Em seguida, é adaptado pela Jurisprudência cautelar (primeiro pontifical, depois laica), que modelava os esquemas e negócios a novos escopos.

A sempre maior complexidade da vida e a expansão do ius gentium e do critério normativo da bona fides ofereceram à interpretatio da Jurisprudência maior campo de aplicação. A publicidade da disputatio, a elasticidade da fides bona, a pesquisa e a elaboração de definições e regras e a sistematização científica caracterizaram um desenvolvimento que multiplicou os direitos reais (firme restando o princípio da tipicidade) e os contratos (delineando-se os múltiplos e complexos efeitos e aspectos).

Também ocorre uma assistência do jurista à obra criativa do pretor, com o oferecimento de aconselhamento técnico. Porém, a posição da Jurisprudência é diversa da interpretatio do ius civile, em que era a própria Jurisprudência, por meio de obra criativa, a revelar o direito. No âmbito do ius honorarium, a concessão do meio processual, do qual se induzia o direito substancial, promanava formalmente da autoridade do pretor, ficando a sugestão da Jurisprudência em uma fase preparatória juridicamente irrelevante. Sobre os institutos do direito pretoriano, a Jurisprudência fazia posterior obra de interpretação e de coordenação com o ius civile, mas ainda aqui a posição de intérprete, diante de uma fonte autoritária bem definida, realizava-se nos limites mais restritos de uma normal interpretação de um texto.

5. Conclusão: a conformação da discussão no Corpus iuris civilis.

Após longa discussão jurisprudencial em tema de determinação das partes lucri et damni, interveio, finalmente, a codificação justinianéia, que pôs fim aos debates 
e ao ius controversum. Em sede de conclusão, apresenta-se, em linhas gerais, o quadro resultante dos debates e fixado no Corpus iuris.

Esse quadro se resume na constatação de que os contratantes, após a consolidação da disciplina no Corpus iuris, podem estabelecer as quotas de admissão na sociedade e de divisão dos lucros e das perdas na forma mais livre, sendo únicos limites aqueles em que um dos contratantes nada contribua ou seja excluído de participar dos lucros. Tal autonomia oferecida aos contratantes permite que pessoas com patrimônios desiguais se relacionem, podendo o contratante menos abonado compensar com a sua atividade. ${ }^{82}$

São Paulo, agosto de 2002.

82. Cf. Cancelli, Società cit. (nota 21), p. 501. 